\title{
The Contribution of Student Activity and Learning Facilities to Learning Independency and its Impact on Mathematics Learning Outcomes in Junior High School
}

\author{
Ainun Rahma Firdausy ${ }^{1}$, Nining Setyaningsih ${ }^{2}$, La Suha Ishabu ${ }^{3}$, Mohamad Waluyo ${ }^{4}$ \\ ${ }^{1,2}$ Education Faculty, Muhammadiyah University of Surakarta, Indonesia \\ ${ }^{3}$ Education Faculty, University of Pattimura, Indonesia \\ ${ }^{4}$ School of Educational Sciences, University of Szeged, Hungary
}

DOI: 10.23917/ijolae.v1i2.8104

Received: January $1^{\text {st }}, 2019$. Revised: January $14^{\text {th }}, 2019$. Accepted: June $19^{\text {th }}, 2019$

Available Online: June $26^{\text {th }}, 2019$. Published Regularly: July $1^{\text {st }}, 2019$

\begin{abstract}
This study aims to: (1) examine the contribution of student activity and learning facilities to mathematical learning outcomes indirectly through learning independence, (2) examine the contribution of student activity and learning facilities to learning independence, (3) test the contribution of student learning independence to results learn math. This type of research is quantitative with the research subjects being all VII grade students of the Muhammadiyah Middle School Surakarta Special Program in 2018/2019. Data collection is done by questionnaire and documentation. The data analysis technique used is path analysis which has previously been carried out in five tests of data analysis prerequisites, namely: normality test with liliefors, linearity test, multicollinearity test, heteroscedasticity test and autocorrelation test. The results of the study with a significance level of 0.05 , namely: (1) there is a contribution of student activity and learning facilities to learning outcomes indirectly through learning independence by $23.9 \%$, (2) there is a contribution of student activity and learning facilities to learning independence by $64 \%$, (3) there is a contribution of learning independence to mathematics learning outcomes of $15.68 \%$.
\end{abstract}

Keywords: learning facilities, student activity, learning independent

\section{Corresponding Author:}

Ainun Rahma Firdausy, Education Faculty, Universitas Muhammadiyah Surakarta, Indonesia

Email:inunrahma29@gmail.com

\section{Introduction}

Mathematics according to Hosnan

(2014: 177) is a subject that requires a high level of understanding and has a relationship with real life. Based on a survey conducted by the Organization for Economic Cooperation and Development (OECD) in 2015 using the Program for International Student Assessment (PISA) test, Indonesia was ranked low in education equity. For mathematics in 2015, Indonesia reached 359 (median) with an average of 403 . This value still places Indonesia below the average of OECD countries which is 490 . In the continuation of the implementation of education there are various factors that influence, where the factor if used will bring education towards a better than before.

Success in the learning process can affect the future produced by Lile, R., \& Bran, C. (2014). This makes students aware of academic support and encourages them to get good grades. However, as reported above, the results of mathematics learning in Indonesia are still the lowest rank in the world. This situation is really ironic when mathe- 
matics is the parent of science but in fact until now it has not been able to become a favorite subject for students. Mathematical subjects are often considered a frightening lesson for most students both at the elementary and upper secondary level. Of course, this is inseparable from the factors that influence it. Factors allegedly can come from the side of students, teachers or the environment. Factors originating from students can include the level of intelligence, activeness, independence and motivation when learning mathematics. While the factors that come from the teacher are the strategies or learning methods used and the readiness of the teacher to master the mathematics learning material. In terms of school, it can be a facility, judging from the availability, completeness and maintenance of available mathematical facilities.

According to Paramita, S., \& Indarwati, T. A. (2015) the activeness of student learning is the ability of students to be active on a regular basis which involves body, mind and all aspect that associated with the learning process. Selim Gunuc's research (2014) in "The Relationship between Student Involvement and Their Academic Achievement" shows a significant academic relationship between student involvement and their academic achievement. Blasco-Arcas, et. al. (2013) study shows the significant of students activity with term of interactivity with peers and teachers on learning performance. They hypothized that students' interactivity will stimulate students to participate in the classroom, develope their engagement in learning and improve the learning performance. In other word, when students are active in a learning, it means that they engage to the learning process and will promote their understanding, performance and achievement (Reyes, et. al., 2012; Wang \& Holcombe, 2010).
Aforementioned factor can only occure in the learning circumtances and controlled by instructor. While the main factor influences the success of learning is student independency or students' self-regulation. Independency or self-regulation in learning is very important even from early chilhood (McClelland \& Cameron, 2012). Evidences of key components of self-regulation predict academic achievement are shown by several studies namely Valiente, et. al. (2008), Liew, et. al. (2008), and Blair \& Razza (2007). Specifically, according to Nagpal (2013) in "Independent Learning and Student Development" implied that independent learning provides significant results on learning outcomes.

Study of external effect influences students' performance by Akomolafe \& Adesua (2016) in "The Impact of Physical Facilities on the Level of Motivation and Academic Performance of Students in High Schools in South West Nigeria" said that there was an influence of facilities in learning on student learning outcomes. Other research with similar interest, Otieno (2010) and Olimi et. al. (2012) reveals that the high physical facilities, human facilities and other facilities can also influence student motivation towards learning. Also supported in research (Rejeki, Setyaningsih, \& Toyib, 2017) which say that the use of LEGO in learning activities supports the understanding of fractions for students both high-ability students and students with low abilities in mathematics. The other research involving the computer based facilities like computer assisted instruction or e-learning resulting the similar evidence (Yusuf \& Afolabi, 2010; Giesbers, 2013).

By those introduction, the authors' purpose of this study is, (1) to examine the contribution of student activity and learning facilities to mathematics learning outcomes 
indirectly through learning independence, (2) examine the contribution of student activity and learning facilities to learning independence, (3) test the contribution of student learning independence to mathematics learning outcomes.

\section{Method}

This type of research is based on the approach of quantitative research. Quantitative research aims to find relationships and explain the causes of change in measurable social facts (testing theories) (Sutama, 2015: 32).

This research was conducted at the Surakarta Muhammadiyah Middle School Special Program, located on Pleret Raya Barat Street, number 9, Banyuanyar, Banjarsari, Surakarta, Central Java, 57137. The subjects of this study were all VII grade students in the odd semester of 2018/2019.

Data analysis techniques in this study using path analysis. Prerequisite tests include normality test with liliefors, linearity test, multicollinearity test, heteroscedasticity test and autocorrelation test. Riduwan and Kuncoro (2013: 115) state that path analysis techniques are used to test the magnitude of the contribution shown by the path coefficients on each path diagram of the causal relationship between exogenous variables $\mathrm{X}_{1}$ and $\mathrm{X}_{2}$ towards endogenous variables $\mathrm{Y}$ and $\mathrm{Z}$.

Data collection techniques used are: (1) questionnaire method used to retrieve student activity data, learning facilities and learning independence, (2) documentation is used to retrieve student learning outcomes data. The learning outcomes used are the scores of the Intermittent Middle Semester Examination of mathematics in seventh grade students of the Muhammadiyah Junior School Surakarta Special Program in 2018/2019. Procedure and data analysis techniques should be emphasized to literature review article. The research stages should be clearly stated.

\section{Result and Discussion}

Mathematics learning outcomes are obtained using the method of the VII grade Midterm Semester Exam Assessment documentation in 2018/2019. There are four variables, namely student activity $\left(\mathrm{X}_{1}\right)$ and learning facilities $\left(\mathrm{X}_{2}\right)$ as independent variables, learning independence $\left(\mathrm{X}_{3}\right)$ as intervening variables and mathematics learning outcomes (Y) as dependent variables. Data from student activity, learning facilities and learning independence were obtained from filling out questionnaires. Before the questions are given to the research sample, validity and reliability tests have been carried out.

Before the hypothesis testing is carried out, the analysis prerequisite test is carried out which includes the normality test, linearity test, multicollinearity test, heteroscedasticity test and autocorrelation test. Based on the results of the analysis prerequisite test, it was found that the five prerequisite tests for this study could be fulfilled. From the normality test, it is obtained that the value of all variables $\left(\mathrm{L}_{\max }\right)$ is less than $\mathrm{L}_{\text {tabel. }}$ Even if the maximum is less than $\mathrm{L}_{\text {tabel }}$ then the data is declared to be normally distributed. So the conclusion is that all variables in this study are normally distributed.

From the linearity test it is filled with the properties where the value of Fcount of each independent variable with the dependent variable is smaller than Ftable. This shows that between variables has a linear relationship.

While from heteroscedasticity test, it was obtained that all p-Value values of each independent variable on the dependent variable were greater than 0.05 . So it can be 
concluded that each variable in this study did not occur heteroscedasticity.

Multicollinearity test aims to determine the existence of correlations between independent variables. The expected regression model is that there is no multicollinearity. From the data of student activeness $\left(\mathrm{X}_{1}\right)$ on learning facilities $\left(\mathrm{X}_{2}\right)$, it was found that the tolerance value $>0.1$ and VIF value $>10$, so that it was concluded that there were no multicollinearity between independent variables.

In the uji autocorrelation the values for each variable are at $d u<d w<4-d u$. This shows that the variables in this study did not occur autocorrelation.

Furthermore, from the collected data, the correlation value between independent variables and dependent variables is sought with the Product Moment correlation formula given data as in Table 1 as follows.

Table 1. Correlation Matrix

\begin{tabular}{lllll}
\hline & $\mathrm{X}_{1}$ & $\mathrm{X}_{2}$ & $\mathrm{X}_{3}$ & $\mathrm{Y}$ \\
\hline $\mathrm{X}_{1}$ & 1 & 0.464 & 0.795 & 0.489 \\
$\mathrm{X}_{2}$ & 1 & 0.287 & 0.231 \\
$\mathrm{X}_{3}$ & & 1 & 0.396 \\
$\mathrm{Y}$ & & & 1 \\
\hline
\end{tabular}

From table 1 shows the correlation value between student activity $\left(X_{1}\right)$ and learning facilities $\left(X_{2}\right)$, namely $r_{x_{2} x_{1}}=0.464$. The correlation between student activity $\left(X_{1}\right)$ and learning independence $\left(X_{3}\right)$ is $r_{x_{\mathrm{g}} x_{1}}=0.795$. The correlation between learning facilities ( $\left.X_{2}\right)$ and learning independence $\left(X_{3}\right)$ is $r_{x_{x_{a}} x_{2}}=$ 0.287 . The correlation between student activity $\left(X_{1}\right)$ and mathematics learning outcomes $(\mathrm{Y})$ is $r_{y x_{1}}=0.489$. The correlation between learning facilities $\left(X_{2}\right)$ and mathematics learning outcomes $(\mathrm{Y})$ is $r_{y x_{z}}=0.231$. The correlation between learning independence (
$\left.X_{3}\right)$ and mathematics learning outcomes (Y) is $r_{y x_{\mathrm{g}}}=0.396$.

Then find the value $\rho_{i j}$ (path coefficient) as follows.

$$
\begin{array}{ll}
\rho_{x_{z} x_{1}}=0.464 & \rho_{y x_{z}}=0.007 \\
\rho_{x_{z} x_{1}}=0.843 & \rho_{y x_{g}}=0.022 \\
\rho_{x_{g} x_{z}}=-0.104 & R_{y x_{g} x_{z} x_{1}}^{2}=0.239 \\
\rho_{y x_{1}}=0.469 & R_{x_{g} x_{z} x_{1}}^{2}=0.640 \\
\rho y \varepsilon=0.761 & \rho_{x_{3} \varepsilon}=0.360
\end{array}
$$

\begin{tabular}{|c|c|c|c|c|}
\hline \multirow{2}{*}{ Variable Influence } & \multicolumn{2}{|c|}{ Causal Influence } & \multirow{2}{*}{ Residual } & \multirow{2}{*}{ Total } \\
\hline & Direct & Indirect Through $\mathrm{X}_{3}$ & & \\
\hline $\mathrm{X} 1$ against $\mathrm{Y}$ & 0.469 & $0.469+(0.843 \times 0.022)$ & & $\begin{array}{l}0.469 \\
0.488\end{array}$ \\
\hline $\mathrm{X}_{2}$ against $\mathrm{Y}$ & 0.007 & $0.007+(-0.104 \times 0.022)$ & & $\begin{array}{l}0.007 \\
0.005\end{array}$ \\
\hline
\end{tabular}

Based on the path coefficient $\left(\rho_{i j}\right)$ above, then direct and indirect (Indirect) variable contributions can be obtained.

Table 2. Direct and Indirect 


\begin{tabular}{lcccc}
\hline \multirow{2}{*}{ Variable Influence } & \multicolumn{2}{c}{ Causal Influence } & Residual & Total \\
\cline { 2 - 3 } & Direct & Indirect Through $\mathrm{X}_{3}$ & & \\
\cline { 1 - 2 } $\mathrm{X}_{1}, \mathrm{X}_{2}$ and $\mathrm{X}_{3}$ aga- & 0.239 & & 0.761 & 1 \\
inst $\mathrm{Y}$ & 0.843 & & 0.843 \\
$\mathrm{X}_{1}$ against $\mathrm{X}_{3}$ & -0.104 & & -0.104 \\
$\mathrm{X}_{2}$ against $\mathrm{X}_{3}$ & 0.640 & & \\
$\mathrm{X}_{1}$ and $\mathrm{X}_{2}$ against & & 0.360 & 1 \\
$\mathrm{X}_{3}$ & 0.022 & & 0.022 \\
$\mathrm{X}_{3}$ against $\mathrm{Y}$ & & & 1 \\
\hline
\end{tabular}

Based on the path coefficient value, the equation $\mathrm{Y}=0.469 \mathrm{X}_{1}+0.007 \mathrm{X}_{2}+0.022 \mathrm{X}_{3}+$ 0.761 is obtained. With the interpretation of each increase of one of the student activeness variables $\left(\mathrm{X}_{1}\right)$ it will improve the mathematics learning outcomes (Y) of 0.469. Each increase in one learning facility variable $\left(\mathrm{X}_{2}\right)$ will increase mathematics learning outcomes (Y) by 0.007 . Each increase in one learning independence variable $\left(\mathrm{X}_{3}\right)$ will increase mathematics learning outcomes (Y) by 0.022 .

Based on the $\mathrm{F}$ test simultaneously with $\alpha=5 \%, \mathrm{~F}_{\text {count }}=4.920$ and $F_{(0,05 ; 3 ; 47)}=2.8$. Where $\mathrm{F}_{\text {count }}>\mathrm{F}_{\text {table }}$ then this indicates that $\mathrm{H}_{0}$ is rejected. So the conclusion is that the activeness of students and learning facilities contribute simultaneously to the results of learning mathematics through learning independence. The contribution of student activeness, learning facilities and independence of learning simultaneously influence the mathematics learning outcomes of $\mathrm{R}_{\text {square }}=$ $0.239=23.9 \%$ and the remaining $76.1 \%$ can be influenced by other factors beyond this study which cannot be explained. Because $\mathrm{H}_{0}$ is rejected, it can be continued with a partial test using the $t$ test.

Based on the t test with $\alpha=5 \%$, it is obtained $t_{\text {count }}=2.043$ and $t_{0.025: 47}=2.012$ where $t_{\text {count }}>t_{0.025 ; 47}$ means $\mathrm{H}_{0}$ is rejected. So that it can be concluded that student ac- tivity contributes significantly to mathematics learning outcomes. There is a direct effect of student activity on mathematics learning outcomes of 0.469 . This shows the magnitude of the contribution of student activity directly affecting mathematics learning outcomes by $21,996 \%$. Basically, active mathematics learning is not passive so that with the activeness of students, it makes students the subject of learning. Where if students become subjects, students will get the full opportunity to be involved in learning so that it will improve the learning outcomes of mathematics. This shows that the activeness of students has a contribution to the learning outcomes of mathematics. This result is supported by research by Lamanauskas \& Augiene (2017) in "The Aspects of Understanding, Situation and Improvement" which shows that student activity has an effect of $51.4 \%$ in doing assignments. In another study it was found that active learning can increase student motivation and when motivation increases it will also influence mathematics achievement to be better too (M., A.A.A. \& Yang, C., 2018)

In the learning facilities variable, it was found that learning facilities did not have a contribution to the learning outcomes of mathematics. This is indicated by the results of $t_{\text {count }}=0.048$ and $t_{0.025 ; 47}=2012$. The results of this study are not in line with Kwakye's research (2013) in the "Availabil- 
ity of Supportive Facilities for Effective Teaching" which says that learning facilities contribute significantly to mathematics learning outcomes. This is possible due to differences in sampling, where in this study the sample used was junior high school students while in Kwakye's study used a sample of high school.

In addition, the equation $X_{3}=$ $0.843 X_{1}-0.104 X_{2}+0.360$ is also obtained. With interpretation, each increase in one student activity variable $\left(X_{1}\right)$ will increase learning independence $\left(X_{3}\right)$ by 0.843 . But for every increase in one learning facility variable $\left(X_{2}\right)$ there will be a decrease in learning independence $\left(X_{3}\right)$ of 0.104 .

From the results of the study also concluded that the activeness of students and learning facilities have contributed simultaneously to learning independence. This is evidenced by the value of $F_{\text {count }}=42,667$ greater than $F_{(0.05 ; 2 ; 48)}=3.23$. The contribution of student activity and learning facilities simultaneously affecting learning independence is equal to $\mathrm{R}_{\text {square }}=0.640=64 \%$. The remaining $36 \%$ can be influenced by other factors outside of this study. Because $\mathrm{H}_{0}$ is rejected, it can be continued with a partial test using the t test.

On the variable of student activity towards learning independence with $\alpha=5 \%$, obtained $t_{\text {count }}=8.636$ and $t_{0.025 ; 47}=2.012$ where it means $t_{\text {count }}>t_{\text {table }}$ which means $\mathrm{H}_{0}$ is rejected. So the activity of students has a significant contribution to learning independence. Students' active contribution directly affects learning independence by $71.06 \%$. With this value shows that the activity of students during mathematics learning greatly affects the independence of student learning. When learning, the more often the teacher gives a stimulus to students, the more active the students will emerge. When stu- dents are increasingly active, independence in learning will also be higher. This is supported by Beaudoin's study (2003) found that it was not easy to correlate student participation with student learning outcomes. Even so, it was found that students who were very participatory in online classes could achieve higher results in learning. It also revealed that online participation does not always damage student learning outcomes.

For the learning facilities variable towards learning independence, it was found that $t_{\text {count }}=-1.065$ and $-t_{0.025 ; 47}=-2.012$. Because $t_{\text {count }}=-1.065>-t_{0.025 ; 47}=-2.012$ then $\mathrm{H}_{0}$ is accepted. So it can be concluded that learning facilities do not have a significant contribution to learning independence. The results of this study are not in line with the research of C. Nerantzi \& C. Despard (2014) who say that the use of LEGO makes participating students feel more relaxed in preparation for discussion and focus on the assessment task ahead. In addition, LEGO can also make students more independent when activities are taking place. The difference it is possible because of differences in the determination of learning facilities that help during learning, in this study less specific for the determination of teaching aids used in learning while for research from C. Nerantzi \& C. Despard (2014) has determined LEGO as learning facilities in learning.

Individual testing of the learning independence variable $\left(\mathrm{X}_{3}\right)$ on mathematics learning outcomes $(\mathrm{Y})$ using the $\mathrm{t}$ test with a significance level of $\alpha=5 \%$, obtained $t_{\text {count }}=$ 3.018 and $t_{0.025 ; 49}=2.021$. Because $t_{\text {count }}>$ $t_{\text {table }}$ then it shows $\mathrm{H}_{0}$ is rejected. So there is a significant contribution to learning independence towards the learning outcomes of mathematics. The contribution of learning independence to mathematics learning out- 
comes is equal to $\left(r_{y_{\mathrm{a}}}\right)^{2}=(0.396)^{2}=$ $15.68 \%$. Where when students have an independence attitude in themselves, they carry out learning activities that are not dependent on their friends so that when a math test is held, students consciously learn to take full responsibility for their learning outcomes. This proves that the higher the independence of students, the higher the learning outcomes. The results of this study are supported by Nagpal (2013) in "Independent Learning and Student Development" which shows that independent learning provides significant results on learning outcomes.

\section{Conclusion}

There is a contribution of student activity and learning facilities simultaneously to the learning outcomes of mathematics through learning independence with the value of $\mathrm{F}_{\text {count }}=4.920$ with $\alpha=5 \%$. The contribution is $23.9 \%$, the remaining $76.1 \%$ can be influenced by other factors outside of this study. The contribution of student activity directly affects the mathematics learning outcomes of $21.996 \%$.

When students have an independence attitude in themselves, they carry out learning activities that are not dependent on their friends so that when a math test is held, students consciously learn to take full responsibility for their learning outcomes. This proves that the higher the independence of students, the higher the learning outcomes. The results of this study are supported by Nagpal (2013) in "Independent Learning and Student Development" which shows that independent learning provides significant results on learning outcomes.

There is a contribution of student activeness and learning facilities simultaneously affecting learning independence with $\mathrm{F}_{\text {count }}=$ 42,667 with $\alpha=5 \%$. The contribution is
$64 \%$, the remaining $36 \%$ can be influenced by other factors beyond the inexplicable research. Students' active contribution directly affects learning independence by $71.06 \%$.

There is a contribution of learning independence to the learning outcomes of mathematics with $\alpha=5 \%$ obtained by the value of tcount $=3.018$. The contribution of learning independence to mathematics learning outcomes is $15.68 \%$.

\section{References}

Akomolafe, C. O. dan Adesua, V. O. (2016). The Impact of Physical Facilities on Students' Level of Motivation and Academic Performance in Senior Secondary Schools in South West Nigeria. Journal of Education and Practice. 7: 38-42.

Alimi, O. S., Ehinola, G. B., \& Alabi, F. O. (2012). School Types, Facilities and Academic Performance of Students in Senior Secondary Schools in Ondo State, Nigeria. International Education Studies, 5(3), 44-48.

Blair, C., \& Razza, R. P. (2007). Relating effortful control, executive function, and false belief understanding to emerging math and literacy ability in kindergarten. Child Development, 78, 647-663.

Blasco-Arcas, L., Buil, I., HernándezOrtega, B., \& Sese, F. J. (2013). Using clickers in class. The role of interactivity, active collaborative learning and engagement in learnin performance. Computers \& Education, 62, 102-110.

Beaudoin, M. (2003) "Learning or Lurking? Tracking the Invisible Online Student". Internet and Higher Education, Volume 5, pp 147-155.

Giesbers, B., Rienties, B., Tempelaar, D., \& Gijselaers, W. (2013). Investigating the relations between motivation, tool use, participation, and performance in an elearning course using web-video conferencing. Computers in Human Behavior, 29(1), 285-292. 
Gunuc, S. (Department of C. E., \& Technologies). (2014). The Relationships between Student Engagement. International Journal on New Trends in Education and Their Implications, 5(4), 216231. Retrieved from http://www. ijote.org/FileUpload/ks63207/File/19..gu nuc.pdf.

Hosnan, M. (2014). Pendekatan saintifik dan kontekstual dalam pembelajaran abad 21: Kunci sukses implementasi kurikulum 2013. Bogor: Ghalia Indonesia.

Kwakye, E. O. (2013). Availability of Supportive Facilities for Effective Teaching. Hipatia Press, 3(2), 130-146.

Lamanauskas, V., \& Augiene, D. (2017). Scientific research activity of students preservice teachers of science at university: The aspect if understanding, situation and improvement. Eurasia Journal of Mathematics, Science and Technology Education. 13(1), 223-236. https://doi.org/ 10.12973/eurasia.2017.00613a.

Liew, J., McTigue, E., Barrois, L., \& Hughes, J. (2008). Adaptive and effortful control and academic selfefficacy beliefs on achie-vement: A longitudinal study of 1 st through $3 \mathrm{rd}$ graders. Early Childhood Research Quarterly, 23, 515-526.

Lile, R., \& Bran, C. (2014). The Assessment of Learning Outcomes. Procedia - Social and Behavioral Sciences, 163, 125-131. https://doi. org/10.1016/j.sbspro.2014.12.297.

M, A. A. A., \& Yang, C. (2018). Impact of Active Learning on Mathematical Achievement : an Empirical Study in Saudi Arabia Primary Schools. International Journal of Innovation and Economic Development, 4 4(2), 58-79. https://doi.org/10.18775/ijied.18497551-7020.2015.42.2005.

McClelland, M. M., \& Cameron, C. E. (2012). Self-regulation in early childhood: Improving conceptual clarity and developing ecologically valid measures. Child development perspectives, 6(2), 136-142.
Nagpal, K., Priyamakhija, James, L., \& Gyanprakash. (2013). Independent Learning and Student Development. IRJC, 2(2), 27-3.

Nerantzi, C., \& Despard, C. (2014). Perspectives in Applied Academic Practice Do LEGO ( ${ }^{\circ}$ Models Aid Reflection in Learning and Teaching, 2(2), 31-36. https://doi. org/10.14297/jpaap.v2i2.81.

Otieno, K. O. (2010). Teaching/learning resources and academic performance in mathematics in secondary schools in Bondo District of Kenya. Asian Social Science, 6(12), 126.

Paramita, S., \& Indarwati, T. A. (2015). Improving Interest, Activeness, and Student Learning Out Come, 328-359. Retrieved

from https://www.researchgate.net/publication 1323546565

Rejeki, S., Setyaningsih, N., \& Toyib, M. (2017). Using LEGO for Learning Fractions, Supporting or Distracting?, 040016(May).

https://doi.org/10.1063/1.4983954.

Reyes, M. R., Brackett, M. A., Rivers, S. E., White, M., \& Salovey, P. (2012). Classroom emotional climate, student engagement, and academic achievement. Journal of educational psycholo$g y, 104(3), 700$.

Sumantri, M. S., \& Satriani, R. (2016). The Effect of Formative Testing and SelfDirected Learning on Mathematics Learning Outcomes. International Electronic Journal of Elementary Education, 8(3), 507-524.

Sutama. (2015). Metode Penelitian Pendidikan Kuantitatif, Kualitatif, PTK dan R\&D. Kartasura: Fairuz Media.

Valiente, C., Lemery-Chalfant, K., Swanson, J., \& Reiser, M. (2008). Prediction of children's academic competence from their effortful control, relationships, and classroom participation. Journal of Educational Psychology, 100, 67-77.

Wang, M. T., \& Holcombe, R. (2010). Adolescents' perceptions of school environment, engage-ment, and academic achievement in middle school. 
American educational research journal, 47(3), 633-662.

Yusuf, M. O., \& Afolabi, A. O. (2010). Effects of Computer Assisted Instruction
(CAI) on Secondary School Students' Performance in Biology. Turkish Online Journal of Educational TechnologyTOJET, 9(1), 62-69. 